\title{
Percutaneous Subdural Tapping for the Treatment of Chronic Subdural Hematoma associated with Coagulopathy due to Advanced Cancer :

\author{
Case Report
}

\author{
Nobuhiko Aoki, M.D., Akihiro Oikawa, M.D., and Tatsuo Sakai, M.D. \\ Department of Neurosurgery, Tokyo Metropolitan Ohkubo Hospital
}

\begin{abstract}
Chronic subdural hematoma associated with advanced cancer poses a management dilemma for neurosurgeons because of its exclusively poor prognosis and coagulopathy. A 55-year-old woman with coagulopathy due to advanced cancer was successfully treated by emergency percutaneous subdural tapping for chronic subdural hematoma presenting transtentorial herniation. The usefulness of this procedure, which is less invasive than conventional burr-hole craniostomy, for patients with coagulopathy and advanced cancer is discussed.
\end{abstract}

(Received December 4, 1995 ; accepted February 7, 1996)

Key words : chronic subdural hematoma, disseminated intravascular coagulopathy, advanced cancer, subdural tapping

Jpn J Neurosurg (Tokyo) $5: 313-316,1996$

\section{Introduction}

Although chronic subdural hematoma is not frequently accompanied by malignancyl), the prognosis of this associatoin is exclusively poor ${ }^{6 / 8)}$. In addition, because this pathological condition is usually complicated by coagulopathy ${ }^{6 / 8)}$, most neurosurgeons seem to get into dilemma about the surgical indication. The authors have long employed percutaneous subdural tapping, as a less invasive procedure, for the treatment of chronic subdural hematoma in adults ${ }^{23)}$. Recently we have encountered an advanced cancer patient with chronic subdural hematoma, for which percutaneous subdural tapping was considered to be a most suitable therapeutic option.

\section{Case report}

A 55-year-old Korean woman was brought to our emergency room on December 19, 1993, in a comatose state. Although her past medical history was unknown, her friend reported that she struck the head against the corner of a refrigerator in August, 1993. She began to have headaches in late September, but spent a normal daily life. She complained of increase in the severity of headaches in early December, and was found to be bed-ridden without significant verval response, on December 18.

On arrival, the neurological examination showed a Glasgow Coma Scale ${ }^{10)}$ of 7 , and bilateral nonreactive pupils $(4.0 \mathrm{~cm}$ in size on the right, and $3.5 \mathrm{~mm}$ on the left). Painful stimuli elicited only minimal movement of the right extremities. Insertion of an indwelling catheter

東京都立大久保病院脳神経外科 $/ \bar{\top} 160$ 新宿区歌舞伎町 2-44-1〔連絡先：青木信彦〕

Address reprint requests to: Nobuhiko Aoki, M. D., Department of Neurosurgery, Tokyo Metropolitan Ohkubo Hospital, 2-44-1 Kabuki-cho, Shinjuku-ku, Tokyo 160, Japan 


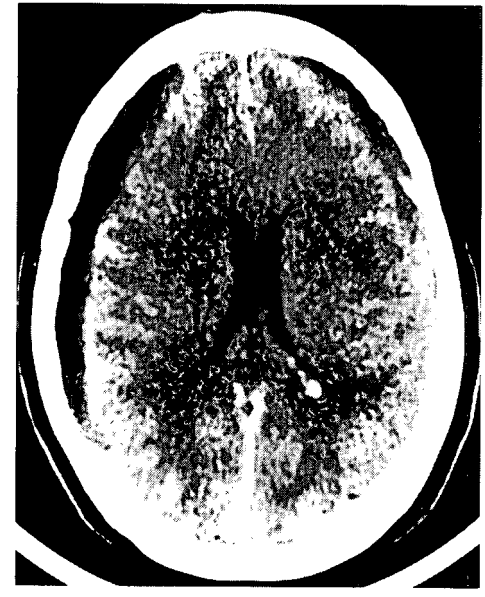

Fig. 1

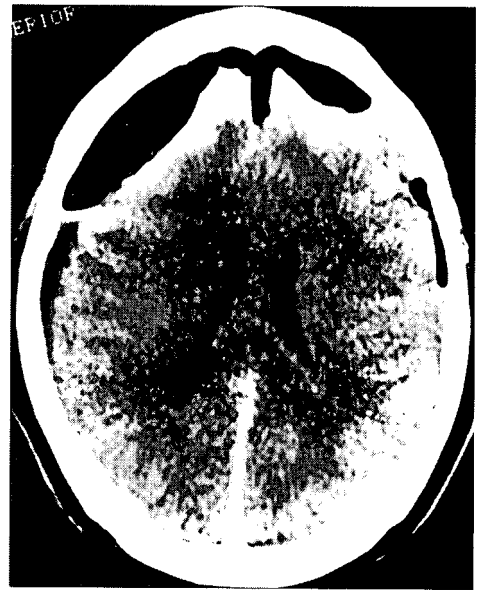

Fig. 2

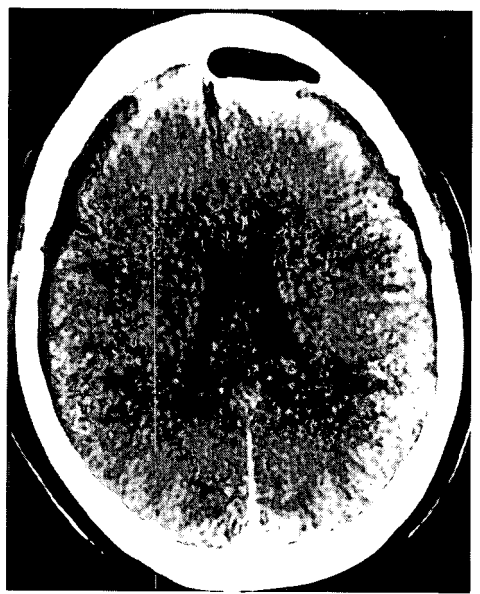

Fig. 3

Fig. 1 A computed tomography scan on admission, showing bilateral chronic subdural hematomas

Fig. 2 A computed tomography scan immediately after replacement of hematomas with oxygen via percutaneous subdural tapping, demonstrating almost complete removal of the hematomas without intracranial hemorrhage

Fig. 3 A computed tomography scan one day after subdural tapping, revealing significant restoration of both cerebral hemispheres together with regression of residual oxygen

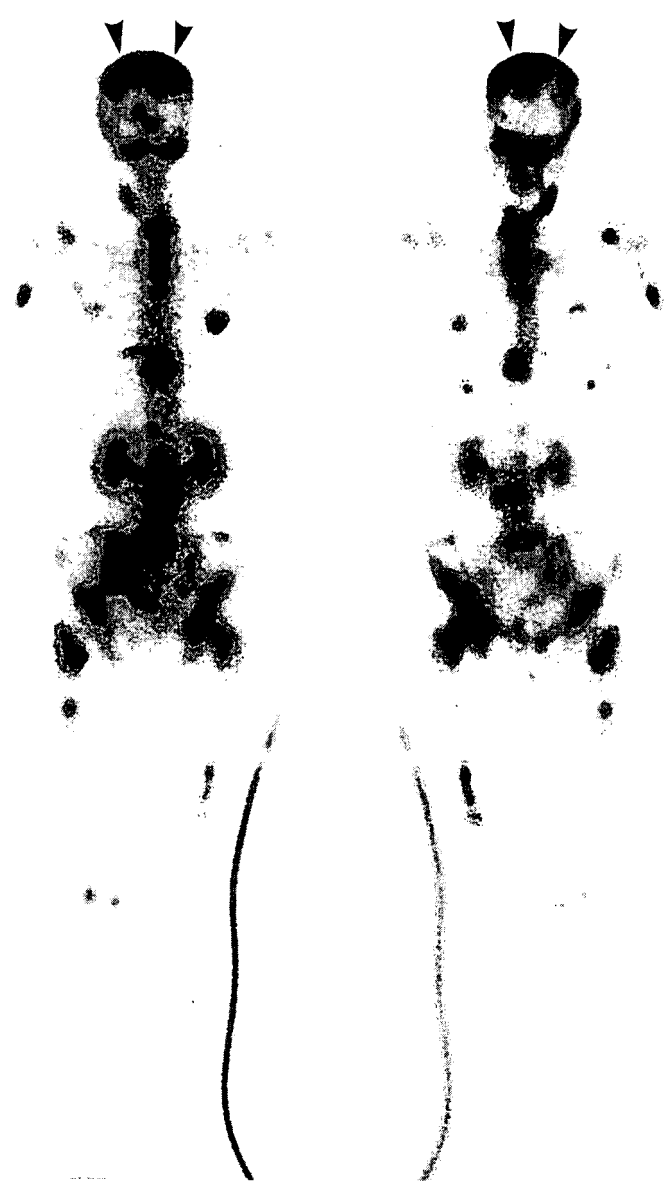

$\bar{A} \mid \mathrm{B}$ Fig. 4 Bone scintigrams with technetuim-99m-methylene diphosphorate delineating multiple high-uptake areas, including those in the calvaria (arrowheads)

A : anteroposterior view

B : posteroanterior view disclosed egress of grossly bloody urine.

Routine hematological examination showed no abnormalities, including platelet count $15.9 \times 10^{4} /$ $\mathrm{mm}^{3}$. Coagulation studies revealed fibrinogen 76 $\mathrm{mg} / \mathrm{d} l$, fibrinogen degradation products $40 \mathrm{ng} /$ $\mathrm{d} l$, prothorombin time $31 \%$ (normal $70-140 \%$ ), and plasminogen 64\% (normal 75-135\%). Results of other laboratory examinations were normal except for carcinoembryonic antigen of $340 \mathrm{ng} /$ $\mathrm{m} l$. These laboratory data and her clinical features indicated bleeding tendency suggestive of disseminated intravascular coagulopathy (DIC), and the presence of malignancy as its pathoetiology. A computed tomography (CT) scan without contrast infusion disclosed chronic subdural hematomas with low density on the right side, and low and isodensity on the left side (Fig. 1).

Immediately following CT examination, she underwent percutaneous subdural tapping at her bedside. Bilateral subdural tapping yielded typical liquid hematoma at a hematoma cavity with a hydrostatic pressure of $20 \mathrm{~cm}$. Sixty $\mathrm{ml}$ of hematoma in each side of the hemisphere was replaced by $60 \mathrm{~m} l$ of oxygen through the subdural needle. A CT scan immediately after the procedure showed almost complete removal of hematomas without abnormal hemorrhage (Fig. 2). Following day, she regained clear consciousness and full motor function. Pupillary abnormality also disappeared. A CT scan on the day 
confirmed significant restoration of both cerebral hemispheres together with regression of residual oxygen (Fig. 3). On December 21 (2 days after admission), subcutaneous hemorrhage developed on the buttock and gingiva without trauma, and decrease in platelet count $\left(11.0 \times 10^{4} / \mathrm{mm}^{3}\right)$ was noted. Her neurological condition was uneventful until December 25, when she began to complain of headaches again. A CT scan revealed reaccumulation of subdural hematoma on the left side, for which replacement of hematoma with $120 \mathrm{~m} l$ of oxygen was performed again through percutaneous subdural tapping. Around the same time, a small subcutaneous mass was observed on the subclavicular region. Biopsy of the lesion yielded a histological diagnosis of metastatic adenocarcinoma, probably from gastric cancer. Because the patient had severe pains on the lumbar region, she underwent bone scintigraphy with technetium-99m-methylene diphosphorate on December 26, which demonstrated multiple highuptake areas, including those in the calvaria (Fig. 4). Her subsequent clinical course was complicated by intolerable low-back pains, which required heavy sedations, resulting in progressive deterioration of consciousness. Her family rejected further treatment, and she died after sudden onset of systemic shock on December 29. No autopsy was granted.

\section{Discussion}

Occurrence of chronic subdural hematoma in cancer patients is known to be caused either by metastasis to the dura mater itself or by accompanying coagulopathy(1)56)8). The present patient was shown to have clinical as well as laboratory features of coagulopathy filling the criteria of DIC. In addition, though no biopsy of the dura mater was undertaken, there is evidence of cranial metastasis delineated by radioisotope scintigrams. Thus, it is reasonable to consider that the pathological condition in this patient was initiated by nontraumatic subdural hemorrhage due to coagulopathy, and then progressed to chronic subdural hematoma with metastasis to its vascular-rich hematoma capsule.

Currently the most popular procedure for the treatment of chronic subdural hematoma is burr hole craniostomy under local or general anesthesia. However, the treatment strategy for this lesion is becoming simpler and less invasive after employment of the twist drill technique ${ }^{7 / 9)}$. The authors also have adopted percutaneous subdural tapping using an original subdural tapping nee$\mathrm{dle}^{2)}$. The procedure recently simplified by replacement of the hematoma with oxygen is less invasive and probably simplest, taking only about 30 minutes for its completion ${ }^{3)}$. The safety of this technique has also been confirmed ${ }^{4)}$. The technical details of this procedure have been described previously'2 ${ }^{4)}$, but the essential parts are as follows. Percutaneous subdural tapping is performed under local anesthesia at the patient's bedside using a subdural needle devised by the author (19 -gauge, Muraishi Iryoki, Tokyo). The skull of adult patient can be penetrated easily with this needle. The needle for transcranial tapping is composed of an outer needle with blunt tip, an inner needle and a needle stylet, and is introduced via a twist-drill technique. Based on the $C T$ findings, the thickest area of the hematoma is percutaneously penetrated perpendicular to the skull. Ten $\mathrm{m} /$ of oxygen in a syringe is slowly injected into the hematoma cavity, and an equal volume of the hematoma is aspirated with the syringe. This procedure is repeated until no more hematoma can be obtained.

Because the patient reported here presented with transtentorial herniation, percutaneous subdural tapping at the bedside on an emergency basis is thought to be the most suitable option of the treatment. In addition, despite suffering definite coagulopathy, this patient was uneventfully treated by percutaneous subdural tapping without adverse hemorrhage related to the procedure. However, occurrence of rebleeding within a few days suggested the necessity of perioperative management for DIC, including administration of heparin and/or nafamostat mesilate. Severity of her neurological condition despite of relatively small volume of the hematoma on the CT scan (Fig. 1) seems to represent rapid bleeding into the subdural cavity due to coagulopathy.

To date, no study on neurosurgical patients with coagulopathy has elucidated whether percutaneous subdural tapping (or the twist drill technique) is less likely complicated by postoperative hemorrhage, compared to conventional burr-hole craniostomy. Our recent experience of patients undergoing hemodialysis (unpublished data) may also support the safety of percutaneous subdural tapping for the treatment of chronic subdural hematoma associated with hemorrhagic 
tendency. Since patients with maligancy have become to enjoy a longer period of survival, it is mandatory to establish safer modalities for the treatment of chronic subdural hematoma with coagulopathy.

To summarize, percutaneous subdural tapping is considered to be appropriately indicated for chronic subdural hematoma in advanced cancer patients, who have exclusively poor prognosis.

\section{References}

1) Ambiavagar PC, Sher J : Subdural hematoma secondary to metastatic neoplasma. Report of two cases and a review of the literature. Cancer 42: 2015-2018, 1974.

2) Aoki N : Subdural tapping and irrigation for the treatment of chronic subdural hematoma in adults. Neurosurgery 14:545-548, 1984.

3) Aoki N: A new therapeutic method for chronic subdural hematoma in adults. Replacement of the hematoma with oxygen via percutaneous subdural tapping. Surg Neurol 38:253-256, 1992.

4) Aoki N, Sakai T: Computed tomography fea- tures immediately after replacement of haematoma with oxygen through percutaneous subdural tapping for the treatment of chronic subdural haematoma in adults. Acta Neurochir (Wien) $120: 44-46,1993$.

5) Braun EM, Burger LJ, Schlang HA : Subdural hematoma from metastatic malignant disease. Cancer 32: 1370-1373, 1973.

6) Furui $T$, Ichihara $K$, Ikeda $A$, Inao $S$, Hirai $N$, Yoshida J, Kageyama N : Subdural hematoma associated with disseminated intravascular coagulation in patients with advanced cancer. $J$ Neurosurg 58:398-401, 1983.

7) Markwalder TM: Chronic subdural hematoma. A review. $J$ Neurosurg 54:637 $-645,1981$.

8) Sugiura $M$, Mori $N$, Sugimori $T$, Imanaga $H$, Kitamura $\mathrm{K}$, Kohno $\mathrm{H}$ : Intracranial hematoma secondary to chronic DIC (in Japanese). No Shinkei Geka 10:295-303, 1982.

9) Tabaddor K, Shulman K : Definite treatment of chronic subdural hematoma by twist-drill craniostomy, and closed-system drainage. $J$ Neurosurg 46:220-226, 1977.

10) Teasdale G, Jennett B : Assessment of coma and impaired consciousness. A practical scale. Lancet ii : 81-94, 1974.

要

旨

凝血異常と進行癌による慢性硬膜下血腫に対して経皮的硬膜下穿刺による治療を行つた1例 青木 信彦 及川 明博 酒井 竜雄

進行癌を伴つた慢性硬暯下血腫は予後不良であることと出血傾向のあることから，その治療は難渋 することが多い.ここでは進行癌と疑血障害による慢性硬膜下血腫を生じた 55 歳の女性について報告 した. 来院時すでにテント切痕へル二ア状態であつたため, 緊急で経皮的硬膜下穿刺による血腫除去 を行い，一時的であうたが，神経症状の消失が得られた。このような症例には侵襲の少ない治療と して，経皮的硬暯下呀刺は有用と考えられた。 